14. Jauss H. R. (1999). Tradycja literacka a dzisiejsza świadomość nowoczesności // Historia literatury jako prowokacja. Warszawa: Instytut Badań Literackich. pp. 9-49.

Gotsaliuk Alla

Doctor of Philosophy,

Associate Professor of the Department of

Event Management and the Leisure Industry, Kyiv National University of Culture and Arts

goz_pravo@ukr.net

ORCID 0000-0002-5171-536X

\title{
NATIONAL TRADITIONS: SPECIFICITY AND PREROGATIVE OF THE FORMATION IN THE ART OF THE ARTISTIC IMAGE OF THE FASHION INDUSTRY OF THE XXI CENTURY
}

The purpose of the article is to determine the features of the inclusion of elements of national traditions in the formation of the artistic image of the fashion industry of the XXI century. Methodology. The research methodology consists of the application of dialectic, analytical methods in order to study the specifics and prerogatives of the formation of an artistic, fashionable image in the modern period, the determination of the factors that influence them; functional and instrumental - to differentiate the role and importance of the formation of a fashionable image in modern culture; comparative - to determine the content of the concepts "fashion", "fashionable image" through the prism of turning to national traditions in the world outlook and axiological aspects. The scientific novelty lies in the fact that for the first time the influence of national cultures on the formation of the artistic image of the fashion industry of the XXI century has been studied. Conclusions. The study concluded that the fashionable artistic image is not just the artist's thinking process but also the final stage of the vision and perception of the world. The research is a form of reflection of the surrounding reality, which is created with the help of various fashion trends in the process of activity of representatives of the fashion industry. It has been established that a fashionable image is a unique vision of the ideal of beauty and an idea of the single character of the reproduction of appearance at a particular historical stage. It was determined that the peculiarities of appeal to national traditions in the art of the artistic image of the fashion industry of the XXI century include: 1) the national tradition remains one of the most productive sources in creating new forms, original compositions, coloristically decorative fashionable images of the modern Ukrainian; 2) the powerful influence of economic factors on the activities in the fashion industry; 3) the enrichment of elements of national traditions with new solutions with the help of modern technical and technological tools, arsenal, techniques and the acquisition of new artistic dimensions by them, most noticeably this is manifested in the modeling of clothes and interior design; 4) the influence of the historical period, social, economic, political components on the formation of the volume of the need to appeal to the elements of national traditions in the fashion industry. dimension.

Key words: fashionable artistic image; fashion; fashionable image; national traditions; fashion trends; fashion industry; artistic

Гоцалюк Алла Анатоліївна, доктор фрілософрських наук, доцент кафредри івент-менеджменту та індустрії дозвілля Київського національного університету культури і мистецтв

Національні традиції у формуванні художньої образності в індустрії моди XXI століття

Метою роботи є визначення особливостей включення елементів національних традицій у формування художнього образу індустрії моди XXI століття. Методологія дослідження полягає у застосуванні діалектичного, аналітичного методів 3 метою дослідження специфріки та прерогатив формування художнього модного образу у сучасний період, визначення фракторів, які на них впливають; функціонально-інструментальний - задля диференціації ролі та значення формування модного образу у сучасній культурі; компаративістський - для визначення змісту понять «мода», «модний образ» через призму звернення до національних традицій у світоглядних та аксіологічних аспектах. Наукова новизна полягає у тому, що уперше досліджено вплив національних традицій на фрормування художнього образу індустрії моди XXI століття. Висновки. У результаті дослідження, зроблено висновок, що модний художній образ - це не просто процес мислення митця, а й завершальний етап його бачення та сприйняття світу; це така форма відбиття навколишньої дійсності, яка створюється за допомогою різноманітних модних тенденцій у процесі діяльності представників модної індустрії. Встановлено, що модний образ - це особливе бачення ідеалу краси і уявлення про унікальний характер відтворення зовнішнього вигляду на певному історичному етапі. Визначено, що до особливостей звернення до національних традицій в мистецтві художнього образу індустрії моди XXI століття слід віднести: 1) національна традиція залишається одним із найпродуктивніших джерел у створенні нових форм, своєрідних композицій, колористичнодекоративних модних образів сучасного українця; 2) потужний влив економічних чинників на діяльність у модній індустрії; 3) збагачення елементів національних традицій новими рішеннями за допомогою сучасних техніко-технологічних інструментів, арсеналу, прийомів та набуття ними нових художніх вимірів, що найбільш примітно у моделюванні одягу та упорядкуванні інтер'єру; 4) вплив історичного періоду, соціальних, економічних, політичних складових на формування обсягу потреби звернення до елементів національних традицій у модній індустрії.

Ключові слова: модний художній образ; мода; модний образ; національні традиції; модні тенденції; модна індустрія; художній вимір.

Гоцалюк Алла Анатолиевна, доктор философських наук, доцент кафредры ивент-менеджмента и индустрии досуга Киевского национального университета культуры и искусств

Национальные традиции: специфика и прерогатива формирования в искусстве художественного образа индустрии моды XXI века

Целью работы является определение особенностей включения элементов национальных традиций у формирование художественного образа индустрии моды XXI века. Методология исследования заключается в применении диалектического, аналитического методов с целью исследования специфики и прерогатив формирования художественного модного образа в современный период, определение факторов, которые на них влияют; функционально-инструментальный - для дифференциа-

(C) Gotsaliuk A., 2019 
ции роли и значения формирования модного образа в современной культуре; компаративистских - для определения содержания понятий «мода», «модный образ» через призму обращения к национальным традициям в мировоззренческих и аксиологических аспектах. Научная новизна заключается в том, что впервые исследовано влияние национальных традиций на формирование художественного образа индустрии моды XXI века. Выводы. В результате исследования сделан вывод, что модный художественный образ - это не просто процесс мышления художника, но и завершающий этап его видения и восприятия мира; это такая форма отражения окружающей действительности, которая создается с помощью различных модных тенденций в процессе деятельности представителей модной индустрии. Установлено, что модный образ - это особое видение идеала красоты и представление об уникальном характере воспроизведения внешнего вида на определенном историческом этапе. Определено, что к особенностям обращения к национальным традициям в искусстве художественного образа индустрии моды XXI века следует отнести: 1) национальная традиция остается одним из самых продуктивных источников в создании новых фрорм, своеобразных композиций, колористически декоративных модных образов современного украинца; 2) мощное влияние экономических фракторов на деятельность в модной индустрии; 3) обогащение элементов национальных традиций новыми решениями с помощью современных технико-технологических инструментов, арсенала, приемов и приобретения ими новых художественных измерений, наиболее примечательно это проявляется в моделировании одежды и составлении интерьера; 4) влияние исторического периода, социальных, экономических, политических составляющих на формирование объема потребности обращения к элементам национальных традиций в модной индустрии.

Ключевые слова: модный художественный образ; мода; модный образ; национальные традиции; модные тенденции; модная индустрия; художественное измерение.

Relevance of the research. The concept of artistic image is basic in art. One of the most advanced forms of art has become the fashion today. Creation of a fashionable artistic vision coordinates the work of many professionals, who are interconnected in some cases with a single ideological concept. At the same time, there is a creative opportunity to create separate fashion trends in different directions: clothes, language, everyday life, hairstyles, visages, style. The fashion definition is associated with all the diversity of the social being of man, and not only with the individual identity. Sometimes we observe a tendency to return to the motives of the past generations, the interweaving of the present of the old-fashioned elements. Therefore, the question of studying the specificity of the formation of the artistic image of the fashion industry of the $\mathrm{XXI}$ century, given the appeal to national traditions, is relevant.

The purpose of the article is to determine the features of the inclusion of elements of national traditions in the formation of the artistic image of the fashion industry of the XXI century.

Analysis of recent research and publications. The question of the study of fashion in the context of artistic practices of the XX century was studied M. Miller [1], the problem of the phenomenon of fashion in the socio-cultural processes of the XX century studied L. Dikhnich [2], the aspect of fashion as an aesthetic phenomenon was illuminated L. Tkachenko [3]. Some issues of examining the social phenomenon of fashion were considered in the writings of such scholars: Z. Tkanko, O. Tkanko, O. Lagodi, O. Naumkina. The study of the artistic image of art was studied by M. Bahhtin, M. Biryukov, L. Buteko, L. Vygotsky, O. Kirichenko, P. Kopnin, L. Masol, Y. Maksimenko, T. Sorochan, G. Shevchenko and others. However, general current trends in the use of the artistic image of the fashion industry of the XXI century to national traditions remain insufficiently studied.

Presenting the main material. First of all, it is necessary to define the basic concepts of research. In our opinion, one of these is the definition of an artistic, fashionable image, which is sometimes simplified by calling "fashionable image," "fashion-image" [4]. It is the concept of the artistic vision through the prism of fashion is transformed, differentiated into a new definition - a creative, fashionable image.

An image is the appearance of someone, something; specific for literature and art is a concretely sensual form of reflection of reality. In science, a particular idea is expressed through concepts, and in art through images; what appears, appears in someone's imagination [5,561]. Artistic - which concerns art, reproduction of reality in images; which relates to art-related art activities; which refers to the perception of phenomena of art or their creation, embodiment, transmission [6, 169].

The artistic image is a specific form of reflection of reality through the prism of a concretely sensual given object of the picture, which refers to a set of individual-objective signs that are activated in the human consciousness [7, 97]. Y. Maksimenko rightly notes: "In art, the concept of" image "is considered in two aspects. In the first - as a designation of the image of a particular hero in the second, the image is interpreted as a holistic form of reflection of the real vision of the world, as an artistic model of this world "[8, 181]. P. Kopnin, analyzing the process of creating an artistic image, notes: "Creation of an artistic image, is really by the general laws of the movement of knowledge. Thus, the artist does not come from the complete idea, which is then embodied in a sensual image, but from an empirical material, from observing the life of people in nature and society. Then he goes to generalizations, to the knowledge of the essence of phenomena, but to others from the scientific knowledge of the path. Science from the sensuously concrete through the abstract goes to concrete in thinking, to the knowledge of the whole in abstractions, but art does not break with the sensual-concrete, it raises it to a generalization of great epistemological, the special and aesthetic value $"[9,72]$. O.Kirichenko argues that the artistic image provides the uniqueness of the role and place of art in the hierarchy of cultural values and the objectivity of the results of artistic creativity [10, 78]. Thus, the creative, fashionable image affects the feelings of the people who perceive it, based on the subjective vision, comprehension, experiences of emotions, experience, socio-cultural values. At the same time, the issue is an outward projection of a fashion specialist based on his subjective reassessment of the external and internal world, for example, the modern human. 
Manifestations of the artistic image, as well as the creative, fashionable vision, are diverse. They correlate with each other generally and particularly. Artistic, stylish models are detailed in specific (individual) varieties, depending on the fashion trends, the means used to reflect the artist's vision, tools, techniques, etc. Also, every pattern of the fashion industry uses its practices. The beginning of the XXI century can be proud of their particular diversity, given the accelerated pace of scientific and technological progress. M. Melnyk states: "The change of the dominant paradigms determines the model of the relationship between artistic practices in the fashion of the beginning of the XXI century, and in connection with the development of technologies and the spread of virtual reality, there are no quantitative changes in the structural relation between types of artistic modeling and design, but also significant qualitative shifts "[11, 55-60].

Scientific and technological progress has led to the emergence of new materials, techniques that are progressively changing. Therefore, it does not seem strange to print clothes on a 3D printer. However, modern fashion experts do not leave the opportunity to combine current technologies with motifs of national traditions, which is most notable in modeling clothes and arranging the interior. Yu. Zhuleid-Khristosenko points out: "Fashion as a phenomenon has always stimulated and stimulates production for the release of a product since society has a steady demand, which in turn generates a proposal. Thus, the mod began to act as the driving force of economic progress "[12, 10].

The fashion industry studies the person, her preferences, tastes and offers a genuinely objectified interpretation of the fashionable modern image of a person. Specialist in fashion as an artist: "... makes people the object of their knowledge, that is, the subject of study is for him all the surrounding reality, material world. Since the tasks of artistic practice condition the need for knowledge of external phenomena, so far as the value of drawing objects is not limited to their utilitarian and practical value, they become meaningful as sources of figurative knowledge of the world, aesthetic perception and the formation of a creative beginning" $[13,95-96]$. Fashion is a phenomenon that can be attributed to art but the fashion industry is naturally an economic ground. Specialists of the fashion industry studying demand and supply can vary within the commercial components of the proposed fashion trends. The production of fashionable clothing can be cheaper or, conversely, make it as expensive as possible. When it comes to traditional national clothing or traditional motifs, then there is also a tendency to increase consumption at a particular time of popularity.

Thus, the fashion industry is a large branch of economic activity, which also includes the protection of intellectual property: a trademark, a brand, a sketch of a drawing, a costume design, etc. In addition, marketing technologies that influence the choice and preferences of the consumer of a fashion product are applied. There is a study of the market and offered new or nostalgic fashionable images. According to experts, the labor force employed in the production of fashion products is about $15 \%$ of the total number used in the fashion industry $[14,62]$.

As for defining fashion. Fashion (French mode, from Latin modus - measure, rule) - the domination at certain times of specific tastes of clothing, items of human consumption, etc., the form of manifestation of culture, the reflection of reality, manifested in the manner of behavior, and mainly in clothes; as a rule, the mode is short-lived and often changes, sometimes returning to the long forgotten [15, 238]. Fashion is a multifaceted phenomenon that reflects the intricate work and interaction of some specialists in the industry: fashion designer, designer, stylist, hairdresser, and others. The development of fashion is directly related to the development of culture, its identity, traditions, attitude to innovation. Specific social, economic, and political features of the state also influence the formation of a fashionable image. It should be said that the mode is a living reflection of the culture of human existence in a particular historical interval; "Integrating into the world fashion system, the domestic mode should reflect the artistic identity of the traditional Ukrainian culture, modernizing it in accordance with the requirements of time" $[1,16]$.

The culture of human existence of the XXI century is reflected in a variety of fashion styles, mixing of styles, in constant innovations, returned to long-forgotten fashion trends and borrowed individual elements, etc. The following statement can illustrate the above: "the Ukrainian art of embroidery has the invaluable importance of the national artistic heritage and at the same time the modern artistic means. Ukrainian folk traditional embroidery, undergoing powerful influence, gradually gets rid of routine elements, enriches the technotechnological arsenal ("satin stitch," "creed stitch," "nyz," "wycinanka (cut)," "openwork embroidery," etc.) and acquires new artistic dimensions " [15-16].

Self-awareness of national identity and patriotic mood of Ukrainians have led to the popularity of a fashionable image associated with national traditions. Thus, such an appeal to traditional Ukrainian is followed by a modern Ukrainian in everything: clothes, hairstyles, and everyday life. However, this does not mean the unilateralism of Ukrainian fashion life in the direction of national traditions. In his daily cultural life, he combines various fashion styles. In our opinion, the choice of fashion style at a particular moment is determined primarily by the appropriateness and comfort of its application.

It is necessary to combine the efforts of all the artists involved in the development of selfrepresentation image to create a fashionable image of a modern person. An idea precedes the conceptual design of the image. The idea is a subjective reflection of the vision of the artist of the artistic image, which consists in the study of contemporary tendencies in the construction of the human system and the possibility of moral borrowing of elements of late fashion periods, and others like that. What is the fashionable image of a modern man of the XXI century in Ukraine? Many fashion designers pose this question. And all the an- 
swers are different. For someone it is an amorphous figure or an eclectic style, for others, it is a classic with a combination of traditional national elements. N. Chuprina points out: "in the second half of the twentieth century, and especially at the turn of the twentieth and twenty centuries, eclecticism actively penetrates into the system of development of mass production clothing, expanding the possibilities of designing single items of clothing as products of the fashion industry for further combinational equipment in terms of consumption" $[17,55]$.

Separately, one can create a fashionable image in clothes, everyday life, hairstyle, and more. Ideological filling of a stylish model may be different: the desire for freedom of choice, self-improvement, loyalty to traditions, etc. Z. Tkanko concludes: "At the beginning of the XXI century clothing becomes a semantically filled object of culture, a reflection of individuality of a person. Apparent in the design of clothing is the shift in emphasis on its conceptual-visual perception and intellectual comprehension. The costume gives the modern person the opportunity to express and shape their own unique image "[18, 35].

M. Melnyk correctly states: "Fashion image is a model of the appearance of a person, offered by the fashion industry and is perceived by consumers of fashion goods and services as the most relevant for a certain period (fashion season). This image combines clothes and accessories, hairstyle and make-up, imitating them, the participant of the fashion expresses his aesthetic taste and creates the own image [4, $\mathrm{p}$. 183]. " I would like to note that in the modern period of development of the Ukrainian language, the fashionable tradition has become an over-saturation with concepts borrowed not only from the Russian language (Russicism) but also from English (Anglo-Russian). Indicative is the use of the very definition of fashionimage, which is fully covered in the Ukrainian-language fashion model.

The process of creating a fashionable image - this is a kind of creative activity, which is the most comprehensive use of self-regulation. Self-regulation is to identify stylish accents, moments of forecasting the further promotion of an elegant image created, the choice of materials and tools, and so on. That is, "selfregulation ... is the plane where the autonomy, privacy of entities can be realized most effectively, which manifests itself in the possibility of creating and fulfilling its own defined rules of conduct" [19, 48], the own vision, opportunities to be realized, self-assertion, etc. Individual self-regulating creativity gives potency for the use of various technical tools, tools, accessories, fabrics, that is, possible new attributes. With the help of creativity, a person can combine united, for example, in an eclectic style or elements of embroidery in a business suit.

National culture, folk art, and costume in particular, as evidenced by the history of fashion of the 20th century, is one of the most productive sources in creating new forms, peculiar compositions, coloreddecorative images of a modern costume. At the same time, the nomination of elements and phenomena of the material culture of the people remains relevant for the cultural science of the XXI century. [20,134].

In modern practice, modern designers are widely used traditional elements. One of these areas is folklorism - the use of ethnic ornamentation or plot lines. The most significant use of traditional motifs appears in the works of such designers: R. Bogutskaya, V. Gres, A. Dats, O. Karavanska, V. Kin, V. Krasnovoy, L. Pustovit, O. Telyazhenko.

O. Naumkina studies the issue of an ethnic, cultural model, summarizes: "The method of introducing ethnic motifs into design practices is the use of elements of Ukrainian ethnic clothing - the elements of cutting, decoration, content and symbolic load. At present, the use of traditional Ukrainian costume elements has traditionally lost its symbolic load (except the continuous line of tradition), while its new place is occupied with new connotations, in the words of a new discourse of fashion "[21, 150]. Contrary to this opinion, O.Lagoda argues: "in the work of Ukrainian designers, the androgynous-marginal images, inherent in antifashion, hippie, punk and Kosar style, were not widely reflected. To a small extent, socio-economic peculiarities have manifested itself, which is due to the objective situation in the political, social and economic life of the country, that the art of costume in Ukraine, developing within decorative and applied arts, enriched and redefined in the modern context, has largely preserved the national color, the national design of clothing is distinguished from among others in the world "[22, 19]. Agreeing in general with the opinion of a specialist, I would still like to add that the development of fashion significantly influences the economic component - the demand for products that for ordinary Ukrainians should be cheap. Therefore, there is an absolute crisis in the aesthetic tastes of consumer goods, the lack of their nationally-filled context. As a rule, a fashion item with traditional elements is more expensive and not always pocket to the general public of Ukraine.

Conclusion. Consequently, a fashionable image is not just a process of thinking of the artist, but also the final stage of his vision and perception of the world. Art stylish model - this is a form of reflection of the reality, which is created by various fashion trends in the process of activity of representatives of the fashion industry. The mentioned issue is a unique vision of the ideal of beauty and an idea of the unique nature of reproduction of the appearance at a particular stage. At the beginning of the XXI century, representatives of various professions work on its formation: stylists, designers, designers, hairdressers, and others.

The peculiarities of appealing to national traditions in the art of the artistic image of the fashion industry of the XXI century include: 1) the national tradition remains one of the most productive sources in creating new forms, peculiar compositions, colorist-decorative fashionable images of modern Ukrainian; 2) a powerful influence of economic factors on the activity in the fashion industry; 3 ) enrichment of elements of national traditions with new solutions with the help of modern technical and technological tools, arsenal, techniques, 
and acquisition of new artistic measurements that is most notable in modeling clothes and arranging the interior; 4) the influence of the historical period, social, economic, and political components on the formation of the volume of the need to appeal to the elements of national traditions in the fashion industry.

\section{תimepamypa}

1. Мельник М.Т. Мода в контексті художніх практик XX ст.: автореф. дис... канд. мистецтвознав.: 26.00.01; Київ. нац. ун-т культури і мистец. К., 2008. 19 с.

2. Дихнич Л.П. Феномен моди в соціокультурних процесах XX століття: авторефр. дис... канд. іст. наук: 17.00.01; Київ. нац. ун-т культури і мистец. К., 2002. 20 с.

3. Ткаченко Л.П. Мода як естетичний феномен: авторефр. дис... канд. філос. наук: 09.00.08; Ін-т філос. ім. Г. С. Сковороди НАН України. К., 1999. 17 с.

4. Мельник М. Т. Стилістична еволюція фешн-образів XX початку XXI ст. Культура і мистецтво у сучасному світі. 2013. Вип. 14. С. $183-188$.

5. Словник української мови: в 11 томах. Том 5, 1974. Стор. 561.

6. Словник української мови: в 11 томах. Том 11, 1980. Стор. 169

7. Галич О.А. Теорія літератури : підручник / Олександр Галич, Віталій Назарець, Євген Васильєв ; за наук. ред. О. Галича. Київ : Либідь, 2001. 488с.

8. Максименко Ю., Синенький Д. Теоретичні засади пізнання художнього образу. Психологія і суспільство. 2009. С. $181-185$.

9. Копнин П. В. Идея как форма мышления / П. В. Копнин. - К. : Изд-во Киевск. ун-та, 1963.

10. Кириченко О. Категорія художнього образу як проблема естетичного освоєння світу в процесі творчої діяльності студентів художньо-графрічного відділення. Наукові записки Кіровоградського державного педагогічного університету імені Володимира Винниченка]. Сер. : Педагогічні науки. - 2016. Вип. 147. С. 77-82.

11. Мельник М. Види художніх фешн-практик на початку XXI століття Матеріали науково-практичної конфреренцій «Художні практики на початку XXI століття: новації, тенденції, перспективи». 25 листопада 2016 року / Київський державний інститут декоративно-прикладного мистецтва і дизайну ім. Михайла Бойчука. К., 2016. 113 с.

12. Жулід-Христосенко Ю.О Теоретичні підходи до креативної складової індустрії моди. Науковий вісник Херсонського державного університету. Серія Економічні науки. Випуск 11. Частина 2. С. 9-12.

13. Бірюков М. Ю. Графічний художній образ як процес пізнання навколишньої дійсності. Вісник Харківської державної академії дизайну і мистецтв. Мистецтвознавство. Архитектура. 2011. № 5. С. 95-97.

14. Shaeffer C. Couture sewing techniques. Taunton Press, 2001. $69 \mathrm{p}$.

15. Тофтул М. Г. Сучасний словник з етики : Словник. - Житомир: Вид-во ЖДУ ім. І. Франка, 2014. 416 с.

16. Варивончик А. В. Традиційна народна вишивка як складова українського одягу XX ст.: автореф. дис... канд. мистецтвознав.: 26.00.01; Київський національний університет культури і мистецтв. Київ, 2011.16 с.

17. Чупріна Н.В., Остапенко Т.М. Еклектизм як засіб формування модних тенденцій в сучасній індустрії моди. Вісник Харківської державної академії дизайну і мистецтв. Мистецтвознавство. Архитектура. 2014. № 2. С.51-55.

18. Тканко 3. Концептуалізм у сучасній моді: теорія і практика проектування Вісник Львівської національної академії мистецтв. 2012. Вип. 23. С. 26-36.

19. Гончаренко О.М. Звичай ділового обороту: засіб саморегулювання господарської діяльності. Зовнішня торгівля: економіка, фінанси, право. 2017. № 6. С. 47-55.

20. Гоцалюк А.А. Соціально-фрілософрський вимір українського одягу. Мультиверсум. Філософський альманах. 2014. Вип. 6-7. С. 134-144.

21. Наумкіна О.С. Етнічний культурний взірець в дизайнерських практиках сучасної України. Культура народов Причерноморья. 2014. № 266. С. 148-152.

22. Лагода О. М. Лагода О.М. Художньо-образні особливості костюма в дизайні одягу кінця XX - початку XXI століття: автореф. дис... канд. канд. мистецтвознав.: 17.00.07; Харківська державна академія дизайну і мистецтв. Харків. 2007. 22 с.

\section{References}

1. Melnyk M.T. (2001). Fashion in the context of artistic practices of the 20th century. Extended abstract of candidate's thesis. p. 19 [in Ukrainian].

2. Dikhnich L.P. (2002). The phenomenon of fashion in the socio-cultural processes of the XX century: Extended abstract of candidate's thesis. p. 20 [in Ukrainian].

3. Tkachenko L.P. (1999). Fashion as an aesthetic phenomenon: author's abstract. Extended abstract of candidate's thesis. p. 17 [in Ukrainian].

4. Miller M. T. Stylistic evolution of fashion models of the XXth century of the XXI century. Culture and art in the modern world. 2013. Issue 14. P. 183-188 [in Ukrainian].

5. Dictionary of the Ukrainian language. (1974). p. 561 [in Ukrainian].

6. Dictionary of the Ukrainian language. (1980). p. 169 [in Ukrainian].

7. Galich O.A. (2001) Theory of Literature. Kyiv. p. 488 [in Ukrainian].

8. Maximenko Yu., \& Sinenky D. (2009). Theoretical foundations of cognition of artistic image. Psychology and Society. pp. 181-185 [in Ukrainian].

9. Kopnin P.V. (1963). The idea as a form of thinking [in Ukrainian].

10. Kirichenko O. (2016). The category of artistic image as a problem of aesthetic development of the world in the creative activity of students of the graphic arts department. Scientific notes of the Volodymyr Vynnychenko. Kirovograd State Pedagogical University. 147. pp. 77-82 [in Ukrainian].

11. Miller M. (2016). Types of art fashion practice at the beginning of the XXI century. Materials of scientific and practical conferences "Art practices in the beginning of the XXI century: innovations, trends, perspectives". Kyiv State Institute of Decorative Arts and Design named after M. Boychuk. Kyiv. p. 113 [in Ukrainian].

12. Zhulid-Khristosenko Yu.O. (n.d.). Theoretical approaches to the creative component of the fashion industry. Scientific Herald of Kherson State University. Series of Economic Sciences. 11. 2. pp. 9-12 [in Ukrainian].

ian].

13. Biryukov M. Yu. (2011). Graphic artistic image as a process of knowledge of the surrounding reality. pp. $95-97$ [in Ukrain-

14. Shaeffer C. (2014). Couture Sewing Techniques. p. 69 [in Ukrainian].

15. Toftul M.G. (2014). Modern Dictionary of Ethics pp. 416 [in Ukrainian].

16. Varivonchik A.V. (2011). Traditional folk embroidery as a component of Ukrainian clothing of the twentieth century. Extended abstract of candidate's thesis. p. 16 [in Ukrainian]. 


\footnotetext{
17. Chuprina N.V., \& Ostapenko T.M. (2014). Eclecticism as a means of forming fashion trends in the modern fashion industry. 2. pp. 51-55 [in Ukrainian].

18. Tkanko Z. (2012). Conceptualism in modern fashion: the theory and practice of designing. pp. 26-36 [in Ukrainian].

19. Goncharenko O.M. (2017). The custom of business turnover: a means of self-regulation of economic activity. 6. pp. 4755 [in Ukrainian].

20. Gotsalyuk A.A. (2014). Socio-philosophical dimension of Ukrainian clothing. 6-7. pp. 134-144 [in Ukrainian].

21. Naumkina O.S. (2014). An Ethnic Cultural Model in Design Practices of Modern Ukraine. 266. pp. 148-152 [in Ukrainian].

22. Lagoda O. M., \& Lagoda O.M. (2007). Artistic-figurative features of a suit in the design of clothing late XX - early XXI century. Extended abstract of candidate's thesis. p. 22 [in Ukrainian].
}

Стаття надійшла до редакції 02.09.2018 p.

УДК 316.776:316.752

\author{
Денисюк Жанна Захарівна \\ доктор культурології, завідувач відділу наукової \\ та редакційно-видавничої діяльності \\ Національної академії керівних кадрів \\ культури і мистецтв \\ ORCID 0000-0003-0833-2993
}

\title{
РЕПРЕЗЕНТАЦІЯ ГЕРОЇКИ В УМОВАХ ІНФОРМАЦІЙНОГО СЕРЕДОВИЩА ТА АКТУАЛІЗАЦІЇ ЕТНОКУЛЬТУРНИХ ЦІННОСТЕЙ
}

\begin{abstract}
Мета дослідження - вивчення репрезентації концепту героїки і героїчного в сучасній культурі за умов превалювання інформаційного середовища та, водночас, актуалізації звернення до етнокультурних цінностей. Методологія дослідження полягає в застосуванні аналітичного, семіотичного та культурологічного методів у вивченні аксіологічної складової у сучасних соціокультурних процесах та, зокрема, її впливу на способи і рівень репрезентації героїчного в сучасній культурі в умовах інформаційного середовища та сучасних комунікацій. Наукова новизна роботи полягає у тому, що вперше розглядається концепт героїки сучасної культури у тісній взаємопов'язаності з етнокультурними цінностями за умов впливу інформаційного середовища. Висновки. В результаті дослідження встановлено, що за останні роки аксіосфера суспільства зазнала певних метаморфоз, пов'язаних із помітним зростанням важливості патріотизму, демократизму, національної свідомості та ідентичності. У ситуації соціокультурної й ціннісної аномії часто відбувається активізація захисних і регулятивних функцій етнокультурних цінностей, що виражається у відповідних реакціях людини, в тому числі й у процесі комунікативної діяльності, що має особливо чіткі прояви в просторі інтернет-комунікації. У сучасному інформаційному просторі це знаходить вияв у пошуку нових героїв і актуалізації концепту героїки і героїчного як репрезентації суспільством потреби в осмисленні соціокультурних реалій, задоволення культурних і духовних потреб і забезпеченні шляхів гармонізації буття.
\end{abstract}

Ключові слова: інформаційно-комунікативне середовище; аксіосфера; ціннісні орієнтації; соціокультурний простір; культурний герой; героїчне.

Денисюк Жанна Захаровна, доктор культурологии, заведующий отделом научной и редакционно-издательской деятельности Национальной академии руководящих кадров культуры и искусств

Репрезентация героики в условиях информационной среды и актуализации этнокультурных ценностей

Цель исследования - изучение репрезентации концепта героики и героического в современной культуре в условиях превалирования информационной среды и одновременно актуализации обращения к этнокультурным ценностям. Методология исследования заключается в применении аналитического, семиотического и культурологического методов в изучении аксиологической составляющей в современных социокультурных процессах и, в частности, ее влияния на способы и уровень репрезентации героического в современной культуре в условиях информационной среды и современных коммуникаций. Научная новизна работы заключается в том, что впервые рассматривается концепт героики в современной культуре в тесной взаимосвязанности с этнокультурными ценностями в условиях воздействия информационной среды. Выводы. В результате проведенного исследования установлено, что за последние годы аксиосфера общества претерпела определенные метаморфозы, связанных с заметным ростом важности патриотизма, демократии, национального сознания и идентичности. В ситуации социокультурной и ценностной аномии часто происходит активизация защитных и регулятивных функций этнокультурных ценностей, что выражается в соответствующих реакциях человека, в том числе и в процессе коммуникативной деятельности, имеет особенно четкие проявления в пространстве интернет-коммуникации. В современном информационном пространстве это проявляется в поиске новых героев и актуализации концепта героики и героического как репрезентации обществом потребности в осмыслении социокультурных реалий, удовлетворения культурных и духовных потребностей и обеспечении путей гармонизации бытия.

Ключевые слова: информационно-коммуникативная среда; аксиосфреры; ценностные ориентации; социокультурное пространство; культурный герой; героическое.

Denysyuk Zhanna, Doctor of cultural studies, Head of research and publishing department of National Academy of Managerial Staff of Culture and Arts

Representation of the hero in the conditions of the informational environment and actualization of ethnocultural val-

ues

The purpose of the article is to study the representation of the concept of heroics and heroic in modern culture in the conditions of the prevailing information environment and, at the same time, to update the appeal to ethnocultural values. The methodology of the research is to apply analytical, semiotic and culturological methods in the study of the axiological component in contemporary socio-cultural processes and, in particular, its influence on the ways and level of representation of the heroic in modern culture in the conditions of the information environment and modern communications. The scientific novelty of the work is that for the first time the concept of heroics of modern culture is considered in close interconnectedness with ethnocultural values under conditions of the influence of information environment. Conclusions. The study found that in recent years, the axiosphere of society has undergone certain metamorphoses, due to the marked increase in the importance of patriotism, democracy, national consciousness, and identity. In a

( Денисюк Ж. З., 2019 